九州大学学術情報リポジトリ

Kyushu University Institutional Repository

\title{
Reproduction Characteristics in Brown Swiss Cows Reared Under Steppe Climate Conditions in Turkey
}

ÇÝLEK, Süleyman

Of Kırıkkale, Faculty of Veterinary Medicine, Department of Animal Breeding

Goto, Takahumi

Kuju Agriculture Research Center, Kyushu University

https://doi.org/10.5109/20196

出版情報：九州大学大学院農学研究院紀要. 56 (2)，pp.287-292，2011-09-20. Faculty of Agriculture, Kyushu University

バージョン：

権利関係 : 


\title{
Reproduction Characteristics in Brown Swiss Cows Reared Under Steppe Climate Conditions in Turkey
}

\author{
Süleyman ÇiLEK ${ }^{1}$ and Takafumi GOTOH ${ }^{2 *}$ \\ ${ }^{1}$ University of Kırıkkale, Faculty of Veterinary Medicine, Department of Animal Breeding, Yahşihan, 71451 Kırıkkale-Turkey \\ ${ }^{2}$ Kuju Agriculture Research Center, Kyushu University, Oita, 878-0201, Japan \\ (Received April 28, 2011 and accepted May 9, 2011)
}

\begin{abstract}
The objective of this study was to investigate the effects of environmental factors on reproductive traits of pure Brown Swiss cows reared under steppe climate conditions in the central Anatolia region of Turkey. In this study, 1502 reproductive records of Brown Swiss cows, which were reared in Ulaş State Farm, were analyzed. The least squares means for gestation period, calving interval, non-pregnant period, insemination number for cows, insemination number per conception for heifers at first insemination, first insemination age, and age at first calving were 287 days, 416 days, 128 days, 1.8 times, 1.6 times, 608 days, and 928 days, respectively. Calving times significantly affected the non-pregnant period, calving interval and gestation period $(\mathrm{P}<0.05)$. The calving intervals were significantly the longest in the $2^{\text {nd }}$ calving time and the shortest in the $8^{\text {th }}$ and $9^{\text {th }}$ calving times $(\mathrm{P}<0.01)$. The birth season of heifers significantly affected first insemination age and age at first calving $(\mathrm{P}<0.01, \mathrm{P}<0.001$, respectively). For the calving season analysis, gestation period was the longest in autumn $(\mathrm{P}<0.01)$. The number of inseminations per conception for cows was significantly larger in spring and autumn than that in summer $(\mathrm{P}<0.01)$. The first calving ages were significantly earlier in autumn than in the other seasons $(\mathrm{P}<0.01)$. For analysis of insemination season, regarding insemination number per conception, first insemination age and first calving age, heifers in spring and summer were significantly larger than those in winter and autumn $(\mathrm{P}<0.01)$. These results suggested that 1$)$ birth and insemination season affected first insemination age and first calving age, 2) Cows born in autumn and winter showed an earlier first insemination and first calving age than in spring and summer, and 3) the same trend would be observed for insemination season.
\end{abstract}

\section{INTRODUCTION}

The Brown Swiss breed of cattle was imported to Turkey from Austria in 1925 to improve milk and meat yield of Turkish native cattle breeds. After this time, cattle with the Brown Swiss genotype were imported from different countries such as Germany and Switzerland, the United States, and Austria. This importation was successful because the adaptation ability of Brown Swiss is excellent (Özbeyaz and Küçük, 1999; Tilki et al., 2003) and the field conditions in Turkey are similar to those in the Alps mountains of Switzerland, which is the origin of Brown Swiss.

Brown Turk cattle were obtained by using a backcross breeding system with different breeds in local areas in Turkey. In the Karacabey stud farm, West Anatolia Brown cattle were developed by backcross breeding Brown Swiss bulls with native gray cows of Turkey. West Anatolia Brown cattle have $96.9 \%$ of the Brown Swiss breed's genotype and $3.1 \%$ of the native gray breed. In similar backcross breeding, eastern Anatolia Browns (Brown Swiss male $\times$ Red female of eastern Anatolia), central Anatolia Browns (Brown Swiss male $\times$ native black female of Anatolia) and south Anatolia Browns (crossbreeding of Brown Swiss with south Anatolian

\footnotetext{
University of Kırıkkale, Faculty of Veterinary Medicine, Department of Animal Breeding, Yah ihan, 71451 Kırıkkale, Turkey

${ }^{2}$ Kuju Agriculture Research Center, Kyushu University, Oita, 878-0201, Japan

* Corresponding author (E-mail: gotoh@farm.kyushu-u.ac.jp)
}

Red) were also accomplished in the eastern Anatolia, central Anatolia, and south Anatolia regions of Turkey, respectively.

Profitable breeding of cattle can be obtained with a high reproductive performance. In breeding, the most important consideration is how environmental factors affect reproduction in a pure breed. Furthermore, to care for these breeds, improvements need to be achieved such as increased reproductive yields of cows in farm management. In this study, we aimed to investigate the effects of environmental factors on reproductive traits of pure Brown Swiss cows reared at Ulaş State Farm under steppe climate conditions in the central Anatolia region of Turkey.

\section{MATERIALS AND METHODS}

In this study, we analyzed 1502 reproductive records of Brown Swiss cows, which were reared in Ulaş State Farm. In the central Anatolia region, the climate is a typical steppe (Fig. 1). There are great temperature differences between day and night. Rainfall is low; however, in winter there is snow. A continental climate prevails in central Anatolia. Summers are hot and dry, and winters are cold and rainy. The mean annual rainfall is $411 \mathrm{~mm}$. The number of days above $30^{\circ} \mathrm{C}$ per year during the investigation was less than 30 and the mean number of days below $0^{\circ} \mathrm{C}$ per year was 120 . There were 30 mean snow days, and 70 days per year during the investigation had snow-covered soil. The temperature during the year ranged between $-30.4{ }^{\circ} \mathrm{C}$ and $+38{ }^{\circ} \mathrm{C}$. Sivas highland plateaus are lush green in spring and autumn, and 


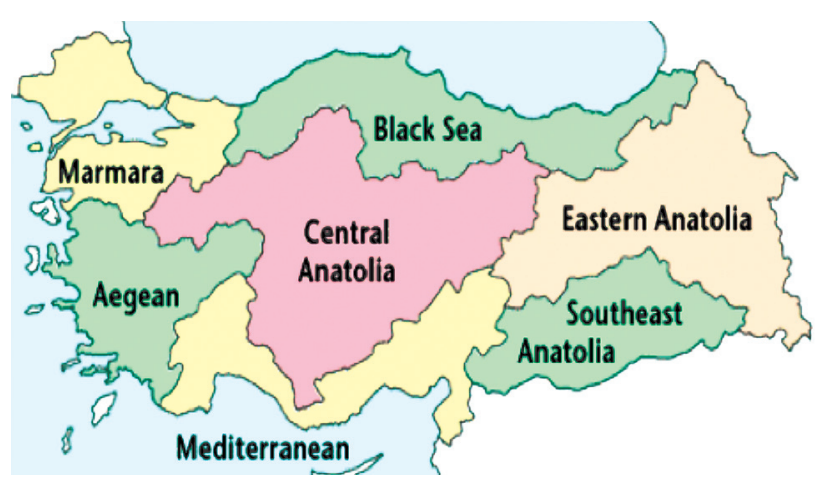

Fig. 1. Map of the central Anatolia region where this study was carried out.

in the summer, they show the appearance of a steppe. The ratio of forest and shrub lands, pastures, and cultivated areas is $11 \%, 43 \%$, and $42 \%$ in Sivas province, respectively

The cattle were fed in the barn throughout the year. The amount of feed for cattle was set according to the level of milk yield by using rations. There were no differences in feeding among seasons. To avoid cold stress, we increased the amount of feed energy during the winter months. Cows were fed during the cool hours in summer to avoid hot stress, as dry grass, sainfoin, vetch, and clover were produced on this farm. Concentrated feed was also used in the rations. Corn silage was performed and used during the year. For cow groups that produced the highest milk yield (more than $25 \mathrm{~kg}$ ), $4 \mathrm{~kg}$ dry grass (sainfoin, vetch, and alfalfa), $15 \mathrm{~kg}$ forage, $9 \mathrm{~kg}$ concentrated feed and $6 \mathrm{~kg}$ barley pulp were given (Total Digestible Nutrients (TDN): $13 \mathrm{~kg}$, total Crude Protein (CP): 2,884 kg). There were no feeding differences among seasons, and cattle were fed with standard rations.

For reproductive traits, first insemination age, age at first calving, calving interval, non-pregnant period, gestation period, insemination number per conception in heifers at first insemination, and insemination number to conception for cows were recorded. An artificial insemination method was used on this farm. The least square means method was used for variance analyses of these reproductive traits. The general linear model was performed using the Minitab packet program (Minitab, 1998) to determine effects of age of the cows, calving years, and calving season on reproductive traits. Duncan's multiple range tests were used for multiple comparisons in important subgroups (Duncan, 1955). In this study, eight calving groups were formed from 2 years and they ended at 9 years of age. For further analysis, four season groups were formed for the calving seasons (winter, spring, summer and autumn). Eight groups for calving years were formed between 2000 and 2007.

For analyzing the gestation period, calving interval, non-pregnant period, and insemination number per conception for cows, we used the following model to analyze effective factors on reproductive traits:

Yijkl $=\mu+$ ai + bj + ck + eijkl

For analyzing the first insemination age, age at first calving, and insemination number per conception for heifers, we used the following model to analyze effective factors on reproductive traits:

Yijkl $=\mu+$ ai $+\mathrm{dj}+\mathrm{fk}+$ eijkl

Yijkl $=$ value of investigated reproductive traits of each cows, $\mu=$ mean reproductive yield of Brown Swiss cow population, ai = effect of the calving year (i), $\mathrm{bj}=$ effect of the calving age (j), ck = effect of the calving season $(\mathrm{k}), \mathrm{dl}=$ effect of the birth season of heifers, $\mathrm{fk}=$ effect of insemination season of heifers and eijkl = error.

\section{RESULTS}

The least square means for the effect of calving years on calving interval, non-pregnant period, gestation period, and insemination number per conception for cows are presented in Table 1. The least squares means for gestation period, calving interval, non-pregnant period, insemination number for cows, insemination number per conception for heifers at first insemination, first insemination age, and age at first calving were 287 days, 416 days, 128 days, 1.8 times, 1.6 times, 608 days, and 928 days, respectively. Calving year had a significant effect on serv-

Table 1. Change in least square means for reproductive traits in all cattle and heifers from 2000 to 2007 in Brown Swiss cows reared in the central Anatolia region of Turkey

\begin{tabular}{|c|c|c|c|c|c|c|c|c|c|c|}
\hline year & 2000 & 2001 & 2002 & 2003 & 2004 & 2005 & 2006 & 2007 & $\begin{array}{l}\text { Total } \\
\text { mean }\end{array}$ & $\mathrm{p}$ value \\
\hline $\begin{array}{l}\text { Traits for all cattle } \\
\text { (number) }\end{array}$ & (202) & $(217)$ & (233) & (186) & (195) & (226) & (205) & $(39)$ & $(1502)$ & \\
\hline gestation period, days & 288 & 287 & 288 & 287 & 287 & 287 & 287 & 287 & 287 & NS* \\
\hline calving interval, days & $456^{\mathrm{a}}$ & $435^{\mathrm{b}}$ & $413^{\text {cd }}$ & $405^{\text {de }}$ & $405^{\mathrm{de}}$ & $433^{\mathrm{c}}$ & $423^{\mathrm{cd}}$ & $359^{\mathrm{e}}$ & 416 & 0.001 \\
\hline non-pregnant period, days & $168^{\mathrm{a}}$ & $148^{\mathrm{b}}$ & $125^{\mathrm{cd}}$ & $117^{\mathrm{d}}$ & $118^{\mathrm{d}}$ & $145^{\text {be }}$ & $135^{\text {bed }}$ & $71^{\mathrm{e}}$ & 128 & 0.001 \\
\hline insemination number /conception, number & $1.9^{\mathrm{b}}$ & $2.0^{\mathrm{ab}}$ & $1.9^{\mathrm{b}}$ & $1.8^{\mathrm{b}}$ & $1.8^{\mathrm{b}}$ & $1.8^{\mathrm{b}}$ & $2.2^{\mathrm{a}}$ & $1.2^{\mathrm{c}}$ & 1.8 & 0.001 \\
\hline $\begin{array}{l}\text { Traits for heifers } \\
\text { (number) }\end{array}$ & (112) & (102) & (29) & (63) & (69) & (81) & (45) & (48) & (619) & \\
\hline insemination number/conception, number & $2.0^{\mathrm{a}}$ & $1.6^{\text {bc }}$ & $1.8^{\mathrm{ab}}$ & $1.3^{\mathrm{cd}}$ & $1.6^{\mathrm{bc}}$ & $1.4^{\text {bcd }}$ & $2.0^{\mathrm{a}}$ & $1.1^{\mathrm{d}}$ & 1.6 & 0.001 \\
\hline first insemination age, days & $591^{\text {cde }}$ & $577^{\mathrm{de}}$ & $652^{\mathrm{ab}}$ & $666^{\mathrm{a}}$ & $580^{\text {de }}$ & $610^{\text {cd }}$ & $625^{\text {bc }}$ & $560^{\mathrm{e}}$ & 608 & 0.001 \\
\hline first calving age, days & $922^{\mathrm{bc}}$ & $889^{\mathrm{d}}$ & $980^{\mathrm{a}}$ & $966^{\mathrm{a}}$ & $898^{\text {cd }}$ & $934^{\mathrm{b}}$ & $983^{\mathrm{a}}$ & $851^{\mathrm{e}}$ & 928 & 0.001 \\
\hline
\end{tabular}

Data show mean. *NS: non-significant. ${ }^{a, b, c, d, e}$ Significant difference between years $(\mathrm{P}<0.01)$. 
ice period, calving interval, insemination number per conception for cows and heifers at first insemination, first insemination age, and age at first calving $(\mathrm{P}<0.001)$, but there was no significant effect of calving year on gestation period $(\mathrm{P}>0.005)$. Calving interval and non-pregnant period were significantly longest in 2000 and shortest in $2007(\mathrm{P}<0.01)$. The number of inseminations to conception was significantly largest in 2007 and smallest in $2006(\mathrm{P}<0.01)$. In heifers, the number of inseminations to conception was significantly largest in 2000 and 2006 and smallest in $2007(\mathrm{P}<0.01)$. The ages at first insemination for conception were significantly latest in 2003 and earliest in $2007(\mathrm{P}<0.01)$. The first calving ages were significantly latest in 2002, 2003 and 2006 and earliest in $2001(\mathrm{P}<0.01)$ (Table 1).

The least square means for the effect of calving age on reproductive traits are presented in Table 2. Calving age significantly affected the non-pregnant period, calving interval and gestation period $(\mathrm{P}<0.05)$. However, the there was no significant effect of calving age on insemination number for cows $(\mathrm{P}>0.05)$. The gestation period was significantly the longest in the $6^{\text {th }}$ calving time $(\mathrm{P}<0.01)$. The calving intervals were significantly the longest in the $2^{\text {nd }}$ calving time and the shortest in the 8th and $9^{\text {th }}$ calving times $(\mathrm{P}<0.01)$. The non-pregnant periods were significantly larger in the $2^{\text {nd }}$ calving time than in the $7^{\text {th }}, 8^{\text {th }}$ and $9^{\text {th }}$ calving times $(\mathrm{P}<0.01$, Table 2$)$.

The least square means for the effect of calving season on reproductive traits are presented in Table 3. Calving season significantly affected gestation period $(\mathrm{P}<0.01)$ and insemination number per conception for cows $(\mathrm{P}<0.05)$ (Table 3$)$. Insemination season of heifers significantly affected insemination number per conception, first insemination age, and age at first calving $(\mathrm{P}<$ $0.001-\mathrm{P}<0.01$ ). However, the birth season of heifers did not significantly affect insemination number per conception for heifers at first insemination $(\mathrm{P}>0.05)$. The birth season of heifers significantly affected first insemination age and age at first calving $(\mathrm{P}<0.01, \mathrm{P}<0.001$, respectively). For the calving season analysis, gestation period was the longest in autumn $(\mathrm{P}<0.01)$. The number of inseminations per conception for cows was significantly larger in spring and autumn than that in summer $(\mathrm{P}<0.01)$. For birth season analysis, the first insemination ages were significantly the latest in spring, followed by summer, and the earliest were in autumn $(\mathrm{P}<0.01)$. The first calving ages were significantly earlier in autumn than in the other seasons $(\mathrm{P}<0.01)$. For analysis of

Table 2. Change in least square means for reproductive traits in calving times in Brown Swiss cows reared in the central Anatolia region of Turkey

\begin{tabular}{lcccccccccc}
\hline \multicolumn{1}{c}{ calving times } & 2 & 3 & 4 & 5 & 6 & 7 & 8 & 9 & $\mathrm{p}$ value \\
\hline Traits & & & & & & & \\
(number) & $(471)$ & $(332)$ & $(248)$ & $(187)$ & $(125)$ & $(86)$ & $(42)$ & $(12)$ \\
gestation period, days & $287^{\mathrm{b}}$ & $287^{\mathrm{b}}$ & $287^{\mathrm{b}}$ & $287^{\mathrm{b}}$ & $291^{\mathrm{a}}$ & $288^{\mathrm{b}}$ & $287^{\mathrm{b}}$ & $286^{\mathrm{b}}$ & 0.05 \\
calving interval, days & $436^{\mathrm{a}}$ & $414^{\mathrm{abc}}$ & $416^{\mathrm{abc}}$ & $421^{\mathrm{abc}}$ & $425^{\mathrm{ab}}$ & $412^{\mathrm{bc}}$ & $399^{\mathrm{c}}$ & $402^{\mathrm{c}}$ & 0.05 \\
non-pregnant period, days & $149^{\mathrm{a}}$ & $128^{\mathrm{ab}}$ & $130^{\mathrm{ab}}$ & $134^{\mathrm{ab}}$ & $135^{\mathrm{ab}}$ & $124^{\mathrm{b}}$ & $112^{\mathrm{b}}$ & $116^{\mathrm{b}}$ & 0.05 \\
insemination number /conception, number & 1.9 & 1.7 & 1.8 & 1.8 & 2.0 & 1.9 & 1.8 & 1.7 & $\mathrm{NS}^{*}$ \\
\hline
\end{tabular}

Data show mean. *NS: non-significant. ${ }^{\mathrm{a}, \mathrm{b}, \mathrm{c}}$ Significant difference between years $(\mathrm{P}<0.01)$

Table 3. Change in least square means for reproductive traits between seasons of calving, birth and insemination in Brown Swiss cows reared in the central Anatolia region of Turkey

\begin{tabular}{|c|c|c|c|c|c|}
\hline year & Winter & Spring & Summer & Autumn & $\mathrm{P}$ value \\
\hline \multicolumn{6}{|l|}{ Traits, calving season } \\
\hline (number) & $(367)$ & $(465)$ & $(377)$ & $(293)$ & \\
\hline gestation period, days & $288^{\mathrm{a}}$ & $286^{\mathrm{b}}$ & $286^{\mathrm{b}}$ & $289^{\mathrm{a}}$ & 0.01 \\
\hline calving interval, days & 417 & 419 & 407 & 420 & NS \\
\hline non-pregnant period, days & 129 & 133 & 120 & 131 & NS \\
\hline insemination number/conception, number & $1.8^{\mathrm{ab}}$ & $1.9^{\mathrm{a}}$ & $1.7^{\mathrm{b}}$ & $1.9^{\mathrm{a}}$ & 0.05 \\
\hline \multicolumn{6}{|l|}{ Traits, birth season } \\
\hline (number) & $(182)$ & $(191)$ & $(153)$ & $(93)$ & \\
\hline insemination number/conception, number & 1.7 & 1.5 & 1.6 & 1.5 & NS \\
\hline first insemination age, days & $603^{\mathrm{b}}$ & $627^{\mathrm{a}}$ & $620^{\mathrm{a}}$ & $580^{c}$ & 0.01 \\
\hline first calving age, days & $935^{\mathrm{a}}$ & $943^{\mathrm{a}}$ & $939^{\mathrm{a}}$ & $894^{\mathrm{b}}$ & 0.001 \\
\hline $\begin{array}{l}\text { Traits, insemination season } \\
\text { (number) }\end{array}$ & $(190)$ & $(143)$ & $(154)$ & $(132)$ & \\
\hline insemination number/conception, number & $1.4^{\mathrm{b}}$ & $1.9^{\mathrm{a}}$ & $1.7^{\mathrm{a}}$ & $1.4^{\mathrm{b}}$ & 0.001 \\
\hline first insemination age, days & $598^{\mathrm{b}}$ & $620^{\mathrm{a}}$ & $616^{\mathrm{a}}$ & $596^{\mathrm{b}}$ & 0.001 \\
\hline first calving age, days & $907^{\mathrm{b}}$ & $955^{\mathrm{a}}$ & $944^{\mathrm{a}}$ & $906^{\mathrm{b}}$ & 0.001 \\
\hline
\end{tabular}

Data show mean. *NS: non-significant. ${ }^{\mathrm{a}, \mathrm{b}, \mathrm{c}, \mathrm{d}}$ Significant difference between years $(\mathrm{P}<0.01)$. 
insemination season, regarding insemination number/ coneption, first insemination age and first calving age, heifers in spring and summer were significantly larger than those in winter and autumn $(\mathrm{P}<0.01)$.

\section{DISCUSSION}

\section{Differences in reproductive characteristics over time (2000-2007)}

In cattle, gestation period is affected by the nutrition of cows, calving age of cows, environmental condition, birth type (twin or single birth), and sex of the calf (Akkayan and Ada, 1974; Stevenson, 1989; Çilek and Tekin, 2007; Kopuzlu et al., 2008). Gestation period for a single male fetus is longer than that for twin female fetuses (Çilek and Tekin, 2005). Gestation periods in pure Brown Swiss in central Anatolia with a steppe climate are consistent with previously reported values between 283 and 287 days in pure Brown Swiss reared in continental and clement climate regions in different countries (Tilki et al., 2003; Çilek and Tekin, 2007; Kopuzlu et al., 2008; Norman et al., 2009; Çilek and Bakır, 2010) (Table 1).

Many previous studies have reported on the nonpregnant period in Brown Swiss cows reared in other climate regions in different countries (Ulusan and Güney 1991, Kaygisız et al., 1996; Çilek and Tekin, 2007; Estrada-Leon et al., 2008; Kopuzlu et al., 2009; Çilek and Bakır, 2010). It has been reported that for cattle breeding, non-pregnant periods between 85 and 110 days are recommended times, and non-pregnant periods longer than 140 days can become a severe problem for the herd (Wattiaux, 1996). In our study, the total mean non-pregnant period was $128 \pm 5$ days, and this was higher than the ideal value. Further studies are required to investigate the reasons for this finding and how to improve it. A longer non-pregnant period than the ideal time suggests unsuccessful insemination management in Brown Swiss cows in this region.

In the current study, days of calving interval and the non-pregnant period gradually became shorter from 2000 to 2007 . This finding indicated that the reproduction cycle of cows became shorter from 2000 to 2007 on this farm. These decreases could be because of improvement of herd management on this farm after 2000; for example, estrus detection, artificial insemination at the appropriate time, and culling of low fertility cows. The number of inseminations per conception did not change throughout the years. Although the effect of first insemination age and first calving age among the years (20002007) was significant in heifers $(\mathrm{P}<0.001)$, there were not any tendencies among the years in comparison between years and all traits (insemination number/conception, first insemination age and first calving age).

Previous reports have shown a calving interval between 383 and 454 days in Brown Swiss cows reared in continental and clement climate regions in different countries (Kaygisız et al., 1996; Magaña et al., 2001; Çilek and Tekin, 2007; Estrada-Leon et al., 2008; Kopuzlu et al., 2009; Cilek and Bakır, 2010). These values in this study are lower than those in tropical regions (Teodoro and Madalena, 2003; Medina et al., 2009). It has been recommended that the calving interval of a cow herd should be 365 days (recommended value), but a calving interval longer than 14 months (427 days) could result in severe problems because it is late for milking (Wattiaux, 1996). Important considerations include accurate detection of estrus, and artificial insemination should be performed at the appropriate time and in the appropriate manner.

In our study, the total mean insemination numbers per conception for heifers and cows from 2000 to 2007 were between 1.6 and 1.8 days, respectively (Table 1 ). In Brown Swiss cows reared in other climate regions, values for insemination number per conception have been previously reported to be between 1.5 and 2.4 days (Ulusan and Güney, 1991; Kaygısız et al., 1996; Estrada, 2006; Çilek and Tekin, 2007; Estrada-Leon et al., 2008; Çilek and Bakır, 2010), and the data in this study are lower than those reported values in tropical regions (Magaña and Segura-Correa, 2001; Estrada-Leon et al., 2008). Lower numbers of insemination per conception indicates better reproductive effects of cattle breeding. Generally, less than 1.7 times for insemination per conception is an appropriate value. More than 2.5 times for insemination per conception can become a severe problem for farm management because of late milk production (Wattiaux, 1996).

In our study, the mean age of first insemination was 608 days. It has been reported that the first insemination age of Brown Swiss cows reared in other climate regions was between 521 and 825 days (Ulusan and Güney, 1991; İnci et al., 2007; Bakır et al., 2009; Kopuzlu et al., 2009; Çilek and Bakır, 2010). In Brown Swiss cows in central Anatolia with a steppe climate, the mean age of first insemination was within the data in previous reports.

The mean first calving age was 928 days in the current study. The mean first calving age in Brown Swiss cows in other regions has been previously reported as 818 days and 1083 days (Magaña et al., 2001; Bayram et al., 2004; Garcia-Peniche et al., 2005; Estrada et al., 2006; Çilek and Bakır, 2010). The first calving age is lower in continental and clement climate regions than that in tropical regions (Magaña and Segura-Correa, 2001; Estrada-Leon et al., 2008).

The first calving age is recommended at 24 months (730 days). An age older than 30 months for first calving (915 days) can become a severe problem for dairy cattle herds (Wattiaux, 1996). Since the milk yield of heifers begins with calving, markets do not desire an age of first calving older than 24 months. Because heifers calved at a mean of 24 months will have a higher lifetime production than those calving later, heifers should be inseminated at 15 months of age. Veterinary medicine of cattle farms should include checking heifers at approximately 15 months of age and be willing to inseminate. Generally, it is known that heifers can be first inseminated when they reach $75 \%$ of the size of their mothers. In Brown Swiss cows reared in the central Anatolia region with a steppe climate, heifers should be successfully fed and 
cared for in an appropriate manner.

\section{Differences in reproductive characteristics among calving times}

Calving times significantly influence reproductive characteristics (Ulusan and Güney, 1991; İnci et al., 2007; Bakır et al., 2009; Kopuzlu et al., 2009; Çilek and Bakır, 2010). A shorter calving interval and non-pregnant period in older cows may be related to an increased number of cows with a high reproductive potential because of culling cows with a low reproductive yield. Furthermore, heifers need to be reared with a high potential of reproduction and distinguish better heifers, which have good ability of reproduction, early.

In the current study, although there was a significant difference in gestation period of cows at the $6^{\text {th }}$ calving time $(\mathrm{P}<0.01)$, totally any tendencies were not found in comparison between calving times and gestation period (Table 2). On the other hand, days of calving interval and the non-pregnant period gradually shortened with an increase in calving times (Table 2). These findings suggest that the reproduction cycle will improve with aging in Brown Swiss cows reared in the steppe climate.

\section{Differences in reproductive characteristics among seasons}

As shown in Table 3, calving season significantly affected gestation duration $(\mathrm{P}<0.01)$. The shortest periods of gestation were in the spring and summer when daylight is long. A shorter period of gestation may be associated with better nutrient and environmental conditions with warmer air temperatures in spring and summer than those in autumn and winter. The longest periods of gestation were in autumn and winter when daylight is short. It has been reported that the length of gestation increases by 1.3 days in relation to the decrease in day length from September to December (Stevenson, 1989). Calving season did not affect the calving interval and non-pregnant period in Brown Swiss cows reared in the steppe climate. The number of inseminations per conception was lower in summer than that in spring and autumn (Table 3). It might have been affected by a marked change in daily air temperature in summer.

Heifers born in autumn indicated a younger age of first insemination and first calving than those born in other seasons. Heifers born in autumn and winter, which can reproduced at a younger age, only experience high air temperatures including heat stress until the first insemination. In the case of heifers born in spring, the time of first insemination is almost 15 months of age when summer arrives. To grow until secondary sex characteristics, the actual period is very important for appropriate development of organs in the calf. Seasonal conditions, especially a change in air temperature and heat stress during the early stage of growth, could affect development of physiological and reproductive function. To avoid heat stress, the seasonal control of reproduction cycles for heifers is needed to produce better Brown Swiss cows in the steppe climate.

\section{CONCLUSION}

Our study showed the reproductive characteristics of Brown Swiss cows reared in the central Anatolia region with a steppe climate. In 2000 to 2007, gestation period, calving interval, non-pregnant period and number of inseminations per conception were within the range reported in the same breed in other climate regions. In heifers, first calving age was later in the central Anatolia region with a steppe climate. Birth and insemination season affected first insemination age and first calving age. Cows born in autumn and winter indicated an earlier first insemination and first calving age than in spring and summer. The same trend was observed for insemination season. For better management, we consider that estrus detection should be accurately performed, and artificial inseminations are performed at the appropriate time and in an appropriate manner for heifers. Moreover, it is also important to consider birth and insemination seasons for cows.

\section{ACKNOWLEDGMENTS}

The authors would like to thank the Ulaş State Farm for support for this research.

\section{REFERENCES}

Bakir, G., S. Keskin, H. Mirtagioglu 2009 Evaluating the relationship between mature age milk yield and several traits using CHAID analysis in Brown Swiss cows. Journal Animal and Veterianry Advances, 8: 587-589

Bayram, B., M. Yanar, Ö. Akbulut 2009 The effect of average daily gain and age at first calving on reproductive and milk production traits of Brown Swiss and milk production traits of Brown Swiss and Holstein Friesain cattle, Bulgarian Journal of Agricultural Sciences, 15: 453-462

Bayram, B., Ö. Akbulut., M. Yanar, N. Tüzemen 2004 Analysis of growth characteristics using the richards model in female Brown Swiss and Holstein Friesian cattle Turkish Journal Veterinary and Animal Sciences, 28: 201-208

Bonetti, O., A. Rossoni, C. Nicoletti 2009 Genetic parameters estimation and genetic evaluation for longevity in italian Brown Swiss bulls. Italian Journal of Animal Science, 8: 30-32

Çilek, S., M. E. Tekin 2007 Environmental factors affecting fertiltiy in cows, Indian Journal Animal Sciences, 77: 236-238

Çilek, S., G. Bakır 2010 Reproductive traits of Anatolian Brown Swiss cows. Bulgarian Journal Animal Sciences, 46: 162171

Duncan W. R. 1955 Multiple Range and Multiple F Tests. Biometrics. 11: 1-42

Estrada, R., J. G. Magana, J. C. Segura 2006 Environmental influences on the reproductive performance of a Brown Swiss cow herd in the tropics of Mexico. Cuban Journal of Agricultural Sciences, 40: 391-399

Estrada-Leon, R. J., J. G.. Magana, J. C. Segura-Correa 2008 Genetic Parameters for reproductive traits of Brown Swiss cows in the Tropics of Mexico, Journal of Animal and Veterinary Advances, 7: 124-129

Garcia-Peniche T. B., B. G. Cassell, R. E. Pearson, I Misztal 2005 Comparisons of Holsteins with Brown Swiss and Jersey Cows on the same farm for age at first calving and first calving interval. Journal of Dairy Sciences, 88: 790-796

Kaygısız A, S. Baş, I. Görentaş 1996 Esmer Sığırların Altındere Tarım işletmesi Şartlarında Adaptasyon ve Verim Özellikleri (The Adaptation and Performance Traits of Brown Cattle Raised at Altındere State Farm). Tarım Bilimleri Dergisi, 2: 
$21-31$

Kopuzlu, S., H. Emsen, A. Özlütürk, A. Küçüközdemir 2008 Esmer ve Siyah alaca ırkı sığırların Doğu Anadolu Tarımsal Araștırma Enstitüsü Şartlarında dölverimi özellikleri (Reproductive Traits of Brown Swiss And Holstein Cattle Under Conditions of East Anatolia Research Institue), Lalahan Hayvancılık Arastırma Enstitüsü Dergisi, 48: 13-24

Magaña, J. G., J. C. Segura-Correa 2001 Estimates of breed and heterosis effects for some reproductive traits of Brown Swiss and Zebu-related breeds in South-eastern Mexico livestock Research for Rural Development, 5: 2001(http://www.cipav. org.co/l rrd//rrd13/5/maga135. htm)

Medina, A. L. M., A. Córdova-Izquierdo, R. S. Robles, G. D. M. Martínez, H. Castillo-Juárez 2009 Breed differences in calving interval in the humid Mexican tropic. Tropical Animal Health Production, 41: 1357-1362

Norman, H. D., J. R. Wright, M. T. Kuhn, S. M. Hubbarda, J. B. Cole, and P. M. VanRaden 2009 Genetic and environmental factors that affect gestation length in dairy cattle. Journal of Dairy Sciences, 92: 2259-2269
SAS., 1998 SAS User's Guide Statistics. SAS Inst, Cary, NC

Stevenson, J. S. 1989 Relationship among climatological variables and hourly distribution of calving in Holsteins fed during the late afternoon. Journal of Dairy Sciences, 72: 27122717

Teodoro, R. L., F. E. Madalena 2003 Dairy production and reproduction by crosses of Holstein, Jersey or Brown Swiss sires with Holstein-Friesian/Gir dams, Tropical Animal Health Production, 35: 105-115

Tilki, M., Ş Inal, M. E. Tekin, M. Çolak 2003 The estimation of phenotypic and genetic parameters for calf birth weight and gestation length of Brown Swiss cows reared at the Bahri Dağdaş International Agricultural Research Institute, Turkish Journal Veterinary and Animal Sciences, 27: 13431348

Ulusan, K. H. O., H. Ö. Güney 1991 Göle Tarım İşletmesinde Karacabey Esmer sığırlarının döl verim performansı (Reproductive performance of Karacabey Swiss cattle reared at Göle state farm. Veterinary Journal of Ankara University, 38: $74-83$ 